\title{
OVIPOSITION OF Bactericera cockerelli (SULC) (HEMIPTERA: TRIOZIDAE) ON Capsicum chinense (JACQ) TREATED WITH SPIROMESIFEN OR SPIROTETRAMAT
}

\author{
OVIPOSICIÓN DE Bactericera cockerelli (SULC) (HEMIPTERA: TRIOZIDAE) EN Capsicum \\ chinense (JACQ) TRATADO CON SPIROMESIFEN O SPIROTETRAMAT
}

\author{
J. Ismael Tucuch-Haas ${ }^{1}$, Gonzalo Silva-Aguayo ${ }^{2}$ y J. Concepción Rodríguez-Maciel*
}

\begin{abstract}
'Instituto Nacional de Investigaciones Forestales, Agrícolas y Pecuarias (INIFAP), Campo Experimental Mocochá, Mocochá, Yucatán, México. ${ }^{2}$ Universidad de Concepción, Facultad de Agronomía, Departamento de Protección Vegetal, Chillán, Chile. ${ }^{3}$ Colegio de Postgraduados, Campus Montecillo, Posgrado en Fitosanidad-Entomología y Acarología, Montecillo, Texcoco, Estado de México, México.
\end{abstract}

*Corresponding author (concho@colpos.mx)

\section{SUMMARY}

The potato/tomato psyllid, Bactericera cockerelli, is one of the most important pests of solanaceous crops in the world. Spirotetramat and spiromesifen are insecticides commonly used against this pest and act by inhibiting acetyl CoA carboxylase, thus preventing the biosynthesis of lipids. Their effect of the insecticides on the oviposition behavior of B. cockerelli on habanero pepper plants, [Capsicum chinense (Jacq)] was evaluated. The foliage of the plant was divided into three strata (upper, middle and lower), and all the strata combinations were treated separately with $30 \mathrm{~mL}$ of the solution at a concentration of $1 \mathrm{~mL} \mathrm{~L}^{-1}$ of commercial formulation using a Potter tower at $0.703 \mathrm{~kg} \mathrm{~cm}^{-2}$ of pressure, calibrated to apply $2 \mathrm{~mL} \mathrm{~cm}^{-2}$. After $1 \mathrm{~h}$ of treatment, the plastic cover was removed from the untreated strata, and the plants of each treatment were infested with 20 pairs of 20 to $24 \mathrm{~h}$-old adults and allowed them to oviposit for $7 \mathrm{~d}$. The number of eggs per leaf per stratum was recorded and its percentage was calculated. The percentage of eggs per leaf in the control at the upper, middle and lower strata was 42,32 and 26 $\%$, respectively. Spiromesifen significantly $(P \leq 0.05)$ inhibited oviposition only in the treated layer. Spirotetramat significantly $(P \leq 0.05)$ reduced the oviposition rate, regardless of the treated stratum, indicating biological activity on untreated parts of the plant, either above or below the treated part.

Index words: Capsicum chinense, chemical control, paratrioza, solanaceae, tetronic acids.

\section{RESUMEN}

El psílido de la papa/tomate, Bactericera cockerelli, es una de las plagas más importantes de cultivos de solanáceas en el mundo. Spirotetramat y spiromesifen son insecticidas comúnmente utilizados contra esta plaga y actúan inhibiendo la acetil CoA carboxilasa, y con ello evitan la biosíntesis de lípidos. Se evaluó el efecto de los insecticidas sobre el comportamiento de oviposición de B. cockerelli en plantas de chile habanero [Capsicum chinense (Jacq)]. El follaje de la planta se dividió en tres estratos (superior, medio e inferior) y todas las combinaciones de estratos se trataron por separado con $30 \mathrm{~mL}$ de la solución a una concentración de $1 \mathrm{~mL} \mathrm{~L}^{-1}$ de formulación comercial, se utilizó una torre Potter a $0.703 \mathrm{~kg} \mathrm{~cm}^{-2}$ de presión, calibrada para aplicar $2 \mathrm{~mL} \mathrm{~cm}^{-2}$. Después de $1 \mathrm{~h}$ de tratamiento se retiró la cubierta plástica de los estratos no tratados, y las plantas de cada tratamiento se infestaron con 20 pares de adultos de 20 a 24 h y se les permitió ovipositar durante $7 \mathrm{~d}$. Se registró el número de huevos por hoja por estrato y se calculó su porcentaje. El porcentaje de huevos por hoja en el testigo en los estratos superior, medio e inferior fue 42,32 y $26 \%$, respectivamente. El Spiromesifen inhibió significativamente $(\mathrm{P} \leq 0.05)$ la oviposición sólo en la capa tratada. El Spirotetramat redujo significativamente $(P \leq 0.05)$ la tasa de oviposición, independientemente del estrato tratado, lo que indica actividad biológica en partes no tratadas de la planta, ya sea por encima o por debajo de la parte tratada.

Palabras clave: Capsicum chinense, ácidos tetrónicos, control químico, paratrioza, solanáceas.

\section{INTRODUCTION}

The potato/tomato psyllid (Bactericera cockerelli) is a pest of great economic importance of solanaceous crops worldwide and causes severe damage to these crops in Mexico, USA, Belize, Honduras and New Zealand (PageWeir et al., 2011). This species attacks 20 botanical families (Liefting et al., 2009) and can complete its biological cycle on 40 plant species (Butler and Trumble, 2012). It constitutes a severe limitation to the production of pepper (Capsicum annuum L.), potato (Solanum tuberosum L.), tomato (Solanum lycopersicum L.) and husk tomato (Physalis philadelphica Lam.) (Garzón-Tiznado et al., 2009). Nymphs and adults feed on the buds producing toxemia Symptoms include leaves yellowing, stunted plant growth and reduced size of fruit or tubers (Gharalari et al., 2009; Sengoda et al., 2010). B. cockerelli also transmits the bacteria Candidatus Liberibacter solanacearum, causing the zebra chip symptom (ZC) (Nachappa et al., 2011).

This disease was firstly detected in 1994 on potato crops from Saltillo, Coahuila, Mexico (Munyaneza et al., 2008), where yellowing foliage and necrosis of the tubers were observed (Muñoz et al., 2016). Also, potato tubers from infected plants develop a pattern of necrotic streaks after being fried (Gharalari et al., 2009; Munyaneza et al., 2008), thus, causing problems for the industry. In tomato, husk 
tomato and chili pepper it causes leaf curl, reduces growth rate and fruit weight loss (Brown et al., 2010; Page-Weir et al., 2011). If the attack is severe, the affected plant dies (Sengoda et al., 2010). The eggplant (Solanum melongena L.) can be a secondary B. cockerelli host, since it is used for feeding (Yang and Liu, 2009).

Habanero pepper is a vegetable of economic importance, demanded by the international and national market not only as food but also as a source of natural dyes and phitochemical compounds such as capsaicinoids (Chan et al., 2011). The market of this compound is increasing since capsaicin is widely used in medicine, cosmetics, paints and as tear gas (López-Gómez et al., 2017). The main pest of the habanero pepper is B. cockerelli (Sulc). This insect pest may cause $100 \%$ loss of yield (Melgoza et al., 2018).

The use of tolerant crops and biological control against this insect pest is of limited efficacy (Butler and Trumble, 2012). Rojas et al. (2015) documented the existence in Mexico of the Tamarixia triozae parasitoid (Burks) (Hymenoptera: Eulophidae), affecting up to 85 $\%$ nymphs; however, Luna-Cruz et al. (2011) indicated that this parasitoid is highly susceptible to commonly used insecticides such as imidacloprid, abamectin, and spinosad, thus preventing their integrated use.

In 2005 and 2008, Bayer Cropscience introduced the insecticides spiromesifen and spirotetramat, both tetronic acids, a group that act by inhibiting the synthesis of acetyl-CoA carboxylase, thus affecting the biosynthesis of lipids (Bielza et al., 2019; Nauen and Konanz, 2005). Spiromesifen is classified as a contact insecticide (Brück et al., 2009), although Kontsedalov et al. (2009) found some translaminar and limited systemic action when applied to the soil or the stem. Spirotetramat has bidirectional systemic action (Nauen et al., 2008), it translocates through both the xylem and phloem (Brück et al., 2009), controlling pests that feed on treated and untreated areas of the plant (Elizondo and Murguido, 2010; Tucuch-Haas et al., 2010). Both compounds exhibit toxicity against eggs and nymphs of the susceptible pests (Elizondo and Murguido, 2010). Additionally, treated females significantly decrease their fecundity and fertility (Nauen et al., 2008; Tucuch-Haas et al., 2010) and do not harm T. triozae (Liu et al., 2012). These insecticides were introduced into Mexican agriculture in 2005 as an alternative for controlling B. cockerelli; although they are effective against this pest, their impact on oviposition behavior is not well understood; thus, this research aimed to determine the effect of localized treatments of spirotetramat and spiromesifen on the behavior of $B$. cockerelli to lay eggs on treated and untreated foliage of habanero chili pepper.

\section{MATERIALS AND METHODS}

\section{Insects and host}

A population of B. cockerelli susceptible to insecticides, previously reproduced for about 103 generations (28 \pm 3 ${ }^{\circ} \mathrm{C}, 50 \pm 4 \%$ relative humidity, 10:14 h light:darkness), free of insecticide exposure, was used. The use of insecticidesusceptible populations avoids any behavioral interference due to a developed capacity to live and reproduce on environments contaminated by toxic compounds. Plants of habanero chili pepper were used as a host of this pest.

\section{Insecticides}

Commercial formulations were used. Oberon ${ }^{\circledR} 240$ SC (spiromesifen, emulsifiable concentrate, $240 \mathrm{~g}$ ai $\mathrm{L}^{-1}$ ) and Movento ${ }^{\circledR}$ OD (spirotetramat, dispersible oil, $150 \mathrm{~g}$ ai $\mathrm{L}^{-1}$ ). For each insecticide, the dose of $1 \mathrm{~mL}$ of commercial product $\mathrm{L}^{-1}$ was used with distilled water as a diluent.

\section{Plants}

Habanero chili pepper plants cv. Criollo Naranja, $30 \pm 3$ $\mathrm{cm}$ in height, were used. This plant condition was reached at about 50 to $55 \mathrm{~d}$ after germination.

\section{Application of insecticides}

Before application, the foliage of the plant was divided into three strata: upper (21 to $30 \mathrm{~cm}$ distal), middle (11 to $20 \mathrm{~cm}$ below the upper stratum) and lower (1 to $10 \mathrm{~cm}$ proximal). A waxed thread delimited each stratum. The untreated strata were covered using a plastic bag $(30 \times$ $20 \mathrm{~cm}$ ) secured with a rubber band. After that, the plant was placed in an acrylic container to be treated using a Potter Tower calibrated to apply $2 \mathrm{mg} \mathrm{cm}^{-2}$, as suggested by Hassan (1985). Thirty $\mathrm{mL}$ of the corresponding insecticide was used and applied at a pressure of 0.703 $\mathrm{kg} \mathrm{cm}^{-2}$. One hour after the application, the protective plastic bags of untreated strata were removed, and the plants were introduced into entomological cages $(70 \times 70$ $\times 100 \mathrm{~cm}$ ); then, infested with 20 pairs of 20 to $24 \mathrm{~h}$-old adults and allow them to lay eggs for $7 \mathrm{~d}$, as suggested by Vega-Gutiérrez et al. (2008). The control was handled in the same way, except that it was treated with $30 \mathrm{~mL}$ of distilled water. After 7 days, the adults were removed from the plants and the number of eggs per leave on each of the three strata were counted. With this information, the percentage of eggs was calculated. 


\section{Experimental design and unit}

The experimental design was a completely randomized blocks with seven treatments, including an untreated control. The experimental unit was a single plant and each treatment had 100 replications (100 plants), carried out on consecutive days.

\section{Statistical analysis}

Analysis of variance was performed using the SAS procedure (SAS Institute, 2012) and means were compared with Tukey test $(P \leq 0.05)$. To achieve homoscedasticity and normality, the response variable was transformed to $\log _{10}(x+1)$. The statistical significance of the studied factors was estimated using the $F$ test $(P \leq 0.05)$ (Gomez and Gomez, 1984).

\section{RESULTS AND DISCUSSION}

\section{Control}

Eggs of $B$. cockerelli were observed in all strata of the plant (Figure 1). The percentage of eggs on the upper, medium and lower strata was 42,32 and $16 \%$, respectively, with significant differences among them $(P \leq 0.05)$. Liu (2004) and Yang and Liu (2009) indicated that this species prefers to lay eggs on the top part or new growths of the plant. Abdullah (2008) and Garzón-Tiznado et al. (2009) argued that females of B. cockerelli colonize the apical parts of the plant because it provides nutritional advantages to offspring. Liu and Trumble (2006) indicated that females prefer to lay eggs between the first and fourth apical leaves of the chili pepper plant. The fourth and fifth instar nymphs are found at the bottom of the plant or on the undersides of the leaves, which is a severe constraint in the use of insecticides to control this pest (Gaskin et al., 2010; Liu, 2004).

Knowledge about the mobility of insecticides within the habanero pepper provides an important basic awareness to consider about their rational use in field conditions. A systemic insecticide (which moves inside the plant) is useful to combat pests in crops whose plants are growing, because new shoots that were not contacted by the application are protected from the attack by the target insect pest; otherwise, insecticides should be used when the plant has completed its growth.

\section{Spiromesifen}

In all cases, the stratum with the lower number of eggs was the treated one $(P \leq 0.05)$ (Figure 2). The average number of eggs was significantly lower in the treated stratum in comparison to the untreated control (Figure 3). Gharalari et al. (2009) observed that when treated the upper part of potato (Solanum tuberosum L.) leaf with spiromesifen, the individuals of $B$. cockerelli living underside were not affected, indicating that this insecticide has contact activity. Also, Chauhan et al. (2018) and LunaCruz et al. (2015) argued that spiromesifen has contact activity, has no movement in the plant and is of low persistence; however, spiromesifen has proven effective in reducing Raoiella indica Hirst populations by more than 95 $\%$ at $7 \mathrm{~d}$ after application (Correa-Méndez et al., 2018).

Liu (2004) documented that spiromesifen is more toxic to adults than to eggs in whitefly feeding on melon

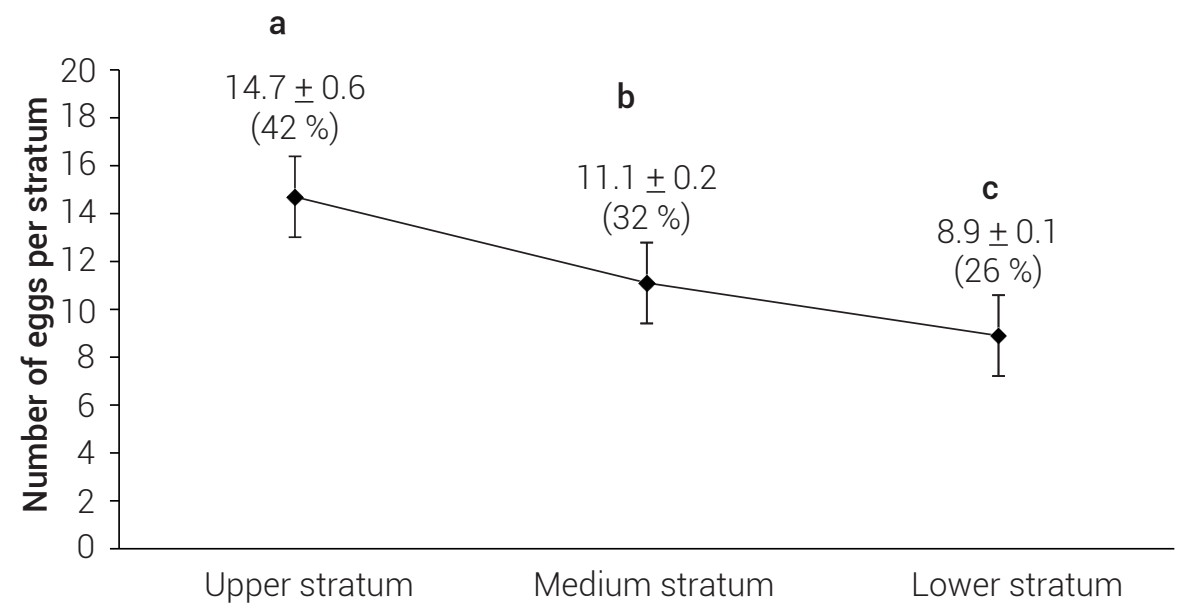

Figure 1. Average number of $B$. cockerelli eggs per stratum of habanero pepper Capsicum chinense (Jacq) plant. The value in parenthesis represents the respective percentage, and the vertical lines indicate the standard error of the respective average. Lowercase letters indicate statistical significance (Tukey, $P \leq 0.05$ ). 
Upper stratum treated
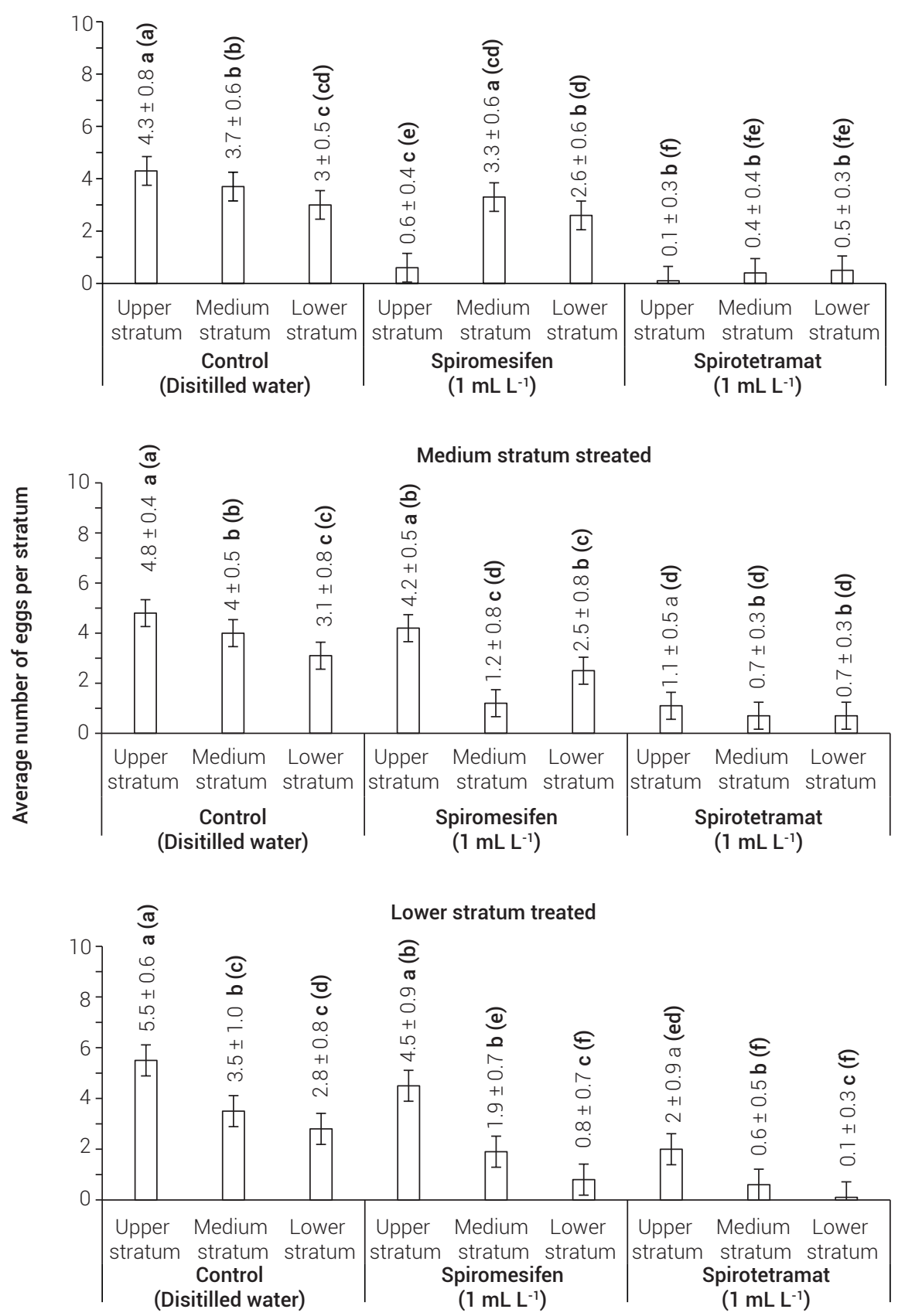

Figure 2. Average number of $B$. cockerelli eggs per stratum of Capsicum chinense (Jacq) plant after $7 \mathrm{~d}$ of treating the respective stratum. Lower case letters indicate statistical significance (Tukey, $\mathrm{P} \leq 0.05$ ).

(Cucumis melo L.) and cabbage (Brassica oleracea L.) plants; moreover, the nymphs that emerged from eggs treated with spiromesifen were unable to molt successfully. Tucuch-Haas et al. (2010) found similar results when treated B. cockerelli with spiromesifen. The decrease in oviposition rate caused by spiromesifen has been, then, commonly found. The length of the bioactivity varies based on the dose used, but the effectiveness of the decrease of oviposition rate has been recorded for 15 days after treatment (Jamieson et al., 2010).

\section{Spirotetramat}

Regardless of the treated stratum, the average number of eggs decreased in all strata. No significant difference was observed in the number of eggs among strata ( $P$ $>0.05)$. Inhibition of oviposition was observed in both treated and in untreated strata, regardless of whether the untreated area was above or below the treated one (Figure $3)$. Once the eggs were laid, the level of mortality was 

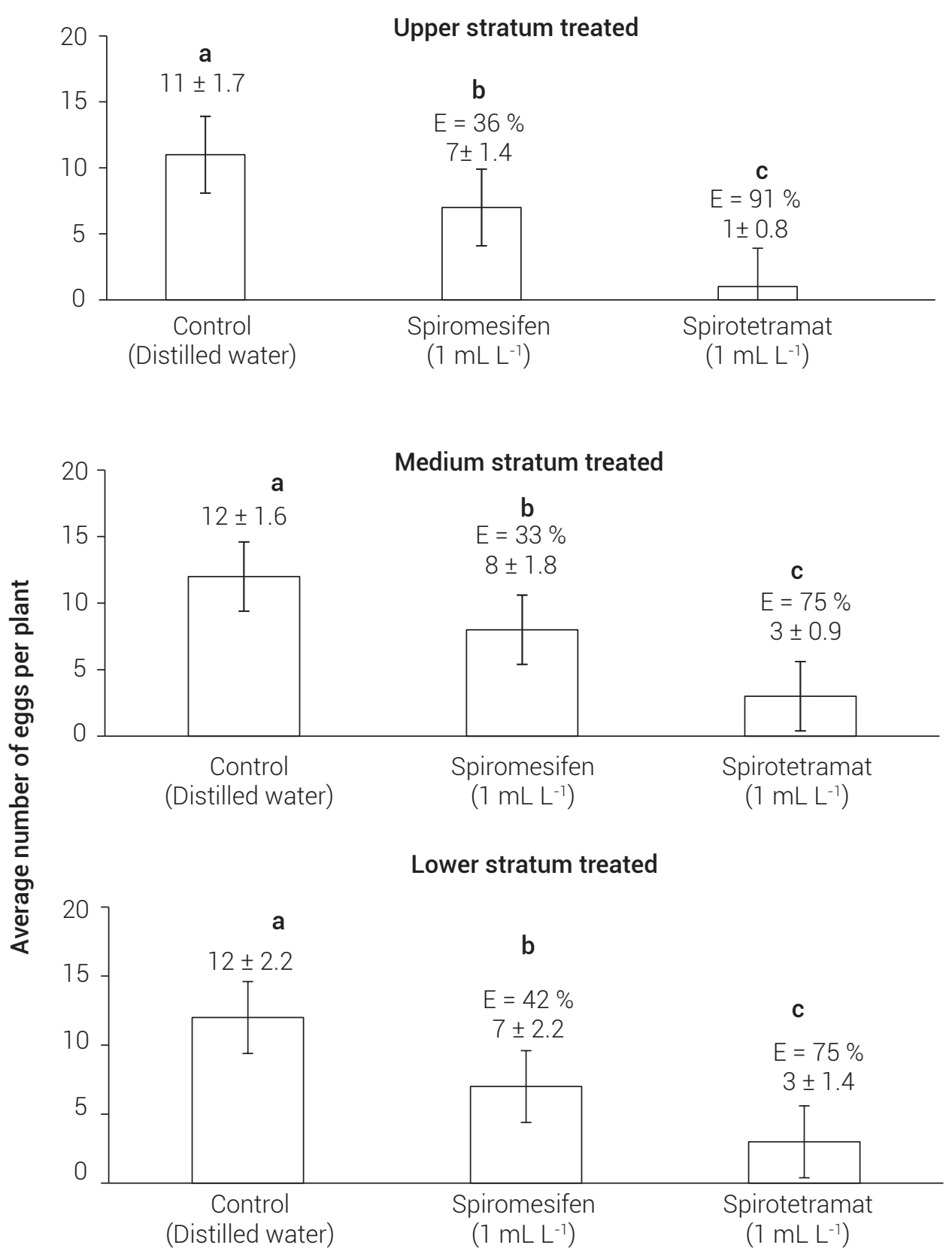

Figure 3. Average number of B. cockerelli eggs laid per plant of chili pepper [Capsicum chinense (Jacq)] and the respective treated stratum. The vertical lines indicate the standard error of the respective average. E: percentage by which control exceeds treatment. Lowercase letters indicate statistical significance (Tukey, $\mathrm{P} \leq 0.05$ ).

less than $3 \%$ on treated as well as on untreated parts of the plants. In consequence, the reduced number of eggs on all strata was not attributed to egg mortality caused by spirotretramat, but to an inhibitory activity on the oviposition of B. cockerelli. These findings (Figures 2 and 3) are in agreement with those of Page-Weir et al. (2011), who observed that spirotetramat was highly effective in reducing egg rate $(P \leq 0.05)$.
There is no scientific information about the effect of spiromesifen and spirotetramat on the oviposition of $B$. cockerelli in habanero pepper; however, the rate of 0.3 and $0.5 \mathrm{~L} \mathrm{ha-1}$ of commercial formulation of spirotetramat can reduce the oviposition rate of various species of plant pests, such as Bemisia tabaci (Gennadius), Thrips palmi (Karny), Tetranychus urticae (Koch) and Myzus persicae (Sulzer) (Elizondo and Murguido, 2010; Marcic et al., 2012) Spirotetramat has been used successfully to reduce the 
fecundity of B. tabaci in horticultural crops (Nauen et al., 2008) as well as that of Orchamoplatus citri (Jamieson et al., 2010). Also, Brück et al. (2009) found that aphids reduced their fertility when plants were treated with spirotetramat. Similarly, Marcic et al. (2012) documented that T. urticae females treated with $200 \mathrm{mg} \mathrm{L}^{-1}$ of spirotetramat reduced their gross fertility (43.7-93.3\%) and their net fertility (73.8$98.5 \%)$ with respect to the control (distilled water).

The eggs laid by females of B. cockerelli, M. persicae, B. tabaci, and T. palmi treated with spirotetramat were unable to complete their biological cycle (Brück et al., 2009; Elizondo and Murguido, 2010; Fiaz et al., 2018; Liu, 2004; Page-Weir et al., 2011; Tucuch-Haas et al., 2010). Taking together, results of this study suggest that field applications of spirotetramat would be feasible to protect against susceptible pests when the plant is growing, and the application of spiromesifen when the plant has completed its growth.

\section{CONCLUSIONS}

The rate of inhibition of oviposition by B. cockerelli was higher in habanero pepper plants treated with spirotetramat compared to those treated with spiromesifen. The spirotetramat significantly reduced the oviposition rate of $B$. cockerelli in the treated and untreated strata of the habanero pepper, regardless of wheter the untreated area is above or below the treated one.

\section{ACKNOWLEDGEMENT}

The authors express sincere thanks to the $7^{\text {th }}$ Research Line (Safety, Food Quality, and Biosafety) of the Postgraduate College for their support to this research. To Bayer CropScience SA of Mexico Ltd. for providing the insecticides spirotetramat and spiromesifen, as well as to Dr. Benigno Estrada Drouailliet for the valuable revision of this document.

\section{BIBLIOGRAPHY}

Abdullah N. M. M. (2008) Life history of the potato psyllid Bactericera cockerelli (Homoptera: Psyllidae) in controlled environment agriculture in Arizona. African Journal of Agricultural Research 3:60-67.

Bielza P., I. Moreno, A. Belando, C. Grávalos, J. Izquierdo and R. Nauen (2019) Spiromesifen and spirotetramat resistance in field populations of Bemisia tabaci Gennadius in Spain. Pest Management Science 75:45-52, https://doi.org/10.1002/ps.5144

Brown J. K., M. Rehman, D. Rogan, R. R. Martin and A. M. Idris (2010) First report of "Candidatus Liberibacter psyllaurous" (synonym "Ca. L. solanacearum") associated with 'tomato vein-greening' and 'tomato psyllid yellows' diseases in commercial greenhouses in Arizona. Plant Disease 94:376376, https://doi.org/10.1094/PDIS-94-3-0376B

Brück E., A. Elbert, R. Fischer, S. Krueger, J. Kühnhold, A. M. Klueken, ... and X. Waetermeulen (2009) Movento ${ }^{\oplus}$, an innovative ambimobile insecticide for sucking insect pest control in agriculture: biological profile and field performance. Crop Protection 28:838-844, https://doi.org/10.1016/j.cropro.2009.06.015

Butler C. D. and J. T. Trumble (2012) The potato psyllid, Bactericera cockerelli (Sulc) (Hemiptera: Triozidae): life story, relationship to plant diseases, and management strategies. Terrestrial Arthropod Reviews 5:87-111, https://doi.org/10.1163/187498312X634266

Chan C. N., E. Sauri D., L. Olivera C. y J. I. Rivas B. (2011) Evaluación de la calidad en la industrialización del chile habanero (Capsicum chinense). Revista Iberoamericana de Tecnología Postcosecha 12:222-226

Chauhan N. R., M. N. Joshi, K. D. Parmar and R. L. Kalsariya (2018) Persistence of spiromesifen 22.9 SC in/on cucumber (Cucumis sativus). Pesticide Research Journal 30:109-111, https://doi.org/10.5958/2249-524X.2018.00018.3

Correa-Méndez A., R. Osorio-Osorio, L. U. Hernández-Hernández, E. de la CruzLázaro, C. Márquez-Quiroz y R. M. Salinas-Hernández (2018) Control químico del ácaro rojo de las palmas Raoiella indica Hirst (Acari: Tenuipalpidae). Ecosistemas y Recursos Agropecuarios 5:319-326, https://doi.org/10.19136/era.a5nl4.1340

Elizondo S. A. I. y C. A. Murguido M. (2010) Spirotetramat, nuevo insecticida para el control de insectos chupadores en el cultivo de papa. Fitosanidad 14:229-234.

Fiaz M., M. Afzal and M. Z. Majeed (2018) Synergistic action of Isaria fumosorosea Wize (Hypocreales: Cordycipitaceae) and spirotetramat against Asian Citrus Psyllid, Diaphorina citri Kuwayama (Hemiptera: Psyllidae) under field conditions. Pakistan Journal of Agricultural Research 31:106-201 https://doi.org/10.17582/journal.pjar/2018/31.2.194.201

Garzón-Tiznado A., G. Cárdenas-Valenzuela, R. Bujanos-Muñiz, A. MarínJarillo, A. Becerra-Flora, S. Velarde-Félix ... y J. Martínez-Carrillo (2009) Asociación de Hemíptera: Triozidae con la enfermedad 'permanente del tomate' en México. Agricultura Técnica en México 35:61-72.

Gaskin R. E., B. D. Horgan, M. R. Leeuwen and W. D. Manktelow (2010) Adjuvant effects on the retention and uptake of spirotetramat insecticide sprays on kiwifruit. New Zealand Plant Protection 63:60-65, https://doi.org/10.30843/nzpp.2010.63.6569

Gharalari A. H., C. Nansen, D. S. Lawson, J. Gilley, J. E. Munyaneza and K. Vaughn (2009) Knockdown mortality, repellency and residual effects of insecticides for control of adult Bactericera cockerelli (Hemiptera: Psyllidae). Journal of Economic Entomology 102:1032-1038, https://doi.org/10.1603/029.102.0322

Gomez K. A. and A. A. Gomez (1984) Statistical Procedures for Agricultural Research. Second edition. John Wiley and Sons. New York USA. 680 p.

Hassan S. A., F. Bigler, P. Blaisinger, H. Bogenschütz, J. Brun, P. Chiverton, ... and A. Q. van Zon (1985) Standard methods to test the side effects of pesticides on natural enemies of insects and mites developed by the IOBC/WPRS Working Group 'Pesticides and Beneficial Organisms'. EPPO Bulletin 15:214-255, https://doi.org/10.1111/j.1365-2338.1985. tb00224.x

Jamieson L. E., N. E. M. Page-Weir, A. Chhagan and C. Curtis (2010) The efficacy of insecticides against Australian citrus whitefly (Orchamoplatus citri). New Zealand Plant Protection 63:254261, https://doi.org/10.30843/nzpp.2010.63.6564

Kontsedalov S., Y. Gottlieb, I. Ishaaya, R. Nauen, R. Horowitz and M. Ghanim (2009) Toxicity of spiromesifen to the developmental stages of Bemisia tabaci biotype B. Pest Management Science 65:5-13, https://doi.org/10.1002/ps.1636

Liefting L. W., B. S. Weir, S. R. Pennycook and G. R. Clover (2009) 'Candidatus Liberibacter solanacearum', associated with plants in the family Solanaceae. International Journal of Systematic and Evolutionary Microbiology 59:2274-2276, https://doi.org/10.1099/ijs.0.007377-0

Liu T. X. (2004) Toxicity and efficacy of spiromesifen, a tetronic acid insecticide, against sweet potato whitefly (Homoptera: Aleyrodidae) on melons and collards. Crop Protection 23:505513, https://doi.org/10.1016/j.cropro.2003.10.006

Liu D. and J. T. Trumble (2006) Ovipositional preferences, damage thresholds, and detection of the tomato-potato psyllid 
Bactericera cockerelli (Homoptera: Psyllidae) on selected tomato accessions. Bulletin of Entomological Research 96:197204, https://doi.org/10.1079/BER2005416

Liu T. X., Y. M. Zhang, L. N. Peng, P. Rojas and J. T. Trumble (2012) Risk assessment of selected insecticides on Tamarixia triozae (Hymenoptera: Eulophidae), a parasitoid of Bactericera cockerelli (Hemiptera: Triozidae). Journal of Economic Entomology 105:490-496, https://doi.org/10.1603/EC11295

López-Gómez J. D., O. G. Villegas-Torres, H. Sotelo N., M. Andrade R., P. Juárez L. y E. Martínez F. (2017) Rendimiento y calidad del chile habanero (Capsicum chinense Jacq.) por efecto del régimen nutrimental. Revista Mexicana de Ciencias Agrícolas 8:17471758, http://doi.org/10.29312/remexca.v8i8.699

Luna-Cruz A., E. Rodríguez-Leyva, J. R. Lomeli-Flores, L. D. Ortega-Arenas, N. Bautista-Martínez and S. Pineda (2015) Toxicity and residual activity of insecticides against Tamarixia triozae (Hymenoptera: Eulophidae), a parasitoid of Bactericera cockerelli (Hemiptera: Triozidae). Journal of Economic Entomology 108: 2289-2295, https://doi.org/10.1093/jee/tov206

Luna-Cruz A., J. R. Lomelí-Flores, E. Rodríguez-Leyva, L. D. Ortega-Arenas y A. Huerta-de la Peña (2011) Toxicidad de cuatro insecticidas sobre Tamarixia triozae (Burks) (Hymenoptera: Eulophidae) y su hospedero Bactericera cokerelli (Sulc) (Hemiptera: Triozidae) Acta Zoológica Mexicana 27:509-526.

Marcic D., S. Petronijevic, T. Drobnjakovic, M. Prijovic, P. Peric and S. Milenkovic (2012) The effects of spirotetramat on life-history traits and population growth of Tetranychus urticae (Acari: Tetranychidae). Experimental and Applied Acarology 56:113122, https://doi.org/10.1007/s10493-011-9500-2

Melgoza V. C. M., C. R. León S., J. Á. López V., L. A. Hernández E., S. Velarde F. y J. A. Garzón T. (2018) Presencia de Candidatus Liberibacter solanacearum en Bactericera cockerelli Sulc asociada con enfermedades en tomate, chile y papa. Revista Mexicana de Ciencias Agrícolas 9:499509, http://doi.org/10.29312/remexca.v9i3.267

Muñoz E. D., P. A. Gutiérrez S. y M. Marín M. (2016) Detección y caracterización molecular del Potato virus Y (PVY) en cultivos de papa (Solanum tuberosum L.) del norte de Antioquia, Colombia. Revista de Protección Vegetal 31:9-19.

Munyaneza J. E., J. L. Buchman, J. E. Upton, J. A. Goolsby, J. M. Crosslin, G. Bester, ... and V. G. Sengoda (2008) Impact of different potato psyllid population on zebra chip disease incidence, severity, and potato yield. Subtropical Plant Science 60:27-37.
Nachappa P., J. Levy, E. Pierson and C. Tamborindeguy (2011) Diversity of endosymbionts in the potato psyllid, Bactericera cockerelli (Hemiptera: Triozidae), the vector of zebra chip disease of potato. Current Microbiology 62:1510-1520 https://doi.org/10.1007/s00284-011-9885-5

Nauen R. and S. Konanz (2005) Spiromesifen as a new chemical option for resistance management in whiteflies and spider mites. Pflanzenschutz Nachrichten Bayer 58:485-502

Nauen R., U. Reckmann, J. Thomzik and W. Thielert (2008) Biological profile of spirotetramat (Movento ${ }^{\circledR}$ ), a new two-way systemic (ambimobile) insecticide against sucking pest species. Bayer CropScience Journal 61:245-278.

Page-Weir E. M., E. L. Jamieson, A. Chhagan, G. P. Connolly and C. Curtis (2011) Efficacy of insecticides against the tomato/potato psyllid (Bactericera cockerelli). New Zealand Plant Protection 64:276-281, https://doi.org/10.30843/nzpp.2011.64.6010

Rojas P., E. Rodríguez-Leyva, J. R. Lomeli-Flores and T. X. Liu (2015) Biology and life history of Tamarixia triozae, a parasitoid of the potato psyllid Bactericera cockerelli. BioControl 60:27-35, https://doi.org/10.1007/s10526-014-9625-4

SAS Institute (2012) SAS ${ }^{\circledR}$ Language Guide for Personal Computers Release 9.0 edition. SAS Institute. Cary, North Carolina, USA. $1028 \mathrm{p}$

Sengoda V. G., J. E. Munyaneza, J. M. Crosslin, J. L. Buchman and H. R. Pappu (2010) Phenotypic and etiological differences between psyllid yellows and zebra chip diseases of potato. American Journal of Potato Research 87:41-49, https://doi.org/10.1007/s12230-009-9115-x

Tucuch-Haas J. I., J. C. Rodríguez-Maciel, A. Lagunes-Tejeda, G. Silva-Aguayo, S. Aguilar-Medel, A. Robles-Bermudez y J. M. González-Camacho (2010) Toxicidad de spiromesifen en los estados biológicos de Bactericera cockerelli (Sulc) (Hemiptera: Triozidae). Neotropical Entomology 39:436 440, https://doi.org/10.1590/S1519-566X2010000300019

Vega-Gutiérrez M. T., J. C. Rodríguez-Maciel, 0. Díaz-Gómez, R. BujanosMuñiz, D. Mota-Sánchez, J. L. Martínez-Carillo, ... and J. A. GarzónTiznado (2008) Susceptibility to insecticides in two Mexican pupulations of tomato-potato psyllid. Bactericera cockerelli (Sulc) (Hemiptera: Triozidae). Agrociencia 42:463-471

Yang X. B. and T. X. Liu (2009) Life history and life tables of Bactericera cockerelli (Homoptera: Psyllidae) on eggplant and bell pepper. Environmental Entomology 38:1661-1667, https://doi.org/10.1603/022.038.0619 
